\title{
Beyond the trouble in the Gulf
}

No amount of resolution by the United Nations can hide the truth that even a quick resolution of the problems created in Kuwait by Iraq (which seems unlikely) will not restore stability to the Middle East.

THE general consternation that the end of the 40-year Cold War should so swiftly be followed by the prospect of serious trouble in the Middle East is understandable, but this disconcerting turn of events is not surprising. Iraq, which annexed Kuwait at the beginning of the month, has only just reached an uneasy stalemate with its neighbour Iran after eight years of warfare that left its economy in ruins and few of its military objectives attained. The general indifference of governments elsewhere to that conflict, both middle-sized powers in the West (such as Britain and France) as well as the then two superpowers (the Soviet Union and the United States) is chiefly explicable by the way in which both combatants kept supplies of oil flowing. Each, after all, had to pay for its military equipment. Such interest as the Iran-Iraq war evoked resulted in mild support for Iraq, given the general distaste for the previous Khomeini regime in Iran. But now the shoe is on the other foot.

Iraq makes no secret of its awkwardness as an adversary. It is equipped with chemical weapons (poison gas) and has experience in their use, both in the war with Iran and against its own population of Kurds, in northern Iraq. It has a supply of long-range surface-to-surface rockets, but little experience of their use. Its flirtation with means for making a huge gun was fanciful, but has probably come to nothing. Iraq is not yet a nuclear power, and is unlikely ever to be one in its own right; one of the disturbing features of this month's developments is that the combination of Iraqi determination and Kuwaiti money may persuade some other states to join in such a venture. But the most menacing development of all is Iraq's apparent willingness to use foreigners caught by accident in its extended borders as hostages in future dealings with governments elsewhere. The unanimity of the UN Security Council in the days following the annexation of Kuwait remains the best hope that order will be restored in the Middle East by legal processes, not military conflict. But it remains to be seen whether the resolution of governments elsewhere will survive televised appeals for compromise by their trapped nationals.

That is one reason why attention should be given now to the causes, rather than the occasion, of the conflict in the Middle East. The underlying difficulty is the revenue from the sale of crude oil earned by states in the Middle East, and the fortuitously unequal distribution of that income. Iraq, with 15 per cent of the total production of the Organization of Oil Exporting Countries (OPEC), was not badly off, but its income from the sale of $\$ 20$-abarrel oil was not sufficient to pay for the war with Iran and is plainly insufficient to sustain its plans to be a substantial military force among Arab states (whence, of course, the move on Kuwait). But Iraq is at least distinguished from the other oil-producers of the Middle East by its plan for spending its oil revenues on a national programme of some kind, being militarily strong in this case. The bulk of what other oil-producing states earn is routinely lent back to the purchasers of oil, usually in the form of credits controlled by named individuals rather than by OPEC governments. The chief effect of 20 years of high-priced oil is that it has created many millionaires among the populations of the Middle East.

The conspicuous failure of the same 20 years has been the poverty of constructive development in the oilproducing states of the Middle East. It is true, of course. that the wealthier governments have set out to provide their people with advanced health services, usually relying on physicians and other paramedical workers from elsewhere to service them. There have also been developments in education, but they are mostly unremarkable. The oil-producers of the Middle East, blessed though they have been with income of the order of $\$ 200,000$ million a year from oil, seem not to have turned their minds to creating a first-rate university somewhere. (The University of Cairo, in impoverished Egypt, remains the Arab world's outstanding university.) Similarly, there has been too little investment in industrial enterprises, even in the downstream processing of oil itself. The oil producers have also spent substantial parts of their funds on preparation to defend themselves and their fortunes; the experience of Kuwait shows how effective that has been. It is no wonder that Kuwait has fallen to Iraq.

There is no way in which the governments now joined in the enterprise of forcing Iraq to retreat from Kuwait can force more enlightened policies on the undemocratic governments elsewhere in the region, but they can at least say loudly and publicly what they think is wrong. Both the vulnerability of the Arab oil-producing states to attacks such as that of Iraq on Kuwait and to Shiite rebellion and revolution are simply consequences of their hierarchical social structure and nepotistic ways of sharing unimagined wealth. While these practices continue, troubles like that which has now arisen are bound to recur. 